\title{
Growth and fiber quality of colored cotton under salinity management strategies
}

\author{
Lauriane A. dos A. Soares ${ }^{1}$, Pedro D. Fernandes ${ }^{1}$, Geovani S. de Lima ${ }^{1}$, \\ Janivan F. Suassuna ${ }^{2}$, Marcos E. B. Brito ${ }^{3} \&$ Francisco V. da S. Sá ${ }^{4}$
} ${ }^{1}$ Universidade Federal de Campina Grande/Centro de Tecnologia e Recursos Naturais/Programa de Pós-Graduação em Engenharia Agrícola. Campina
Grande, PB. E-mail: laurispo.agronomia@gmail.com (Corresponding author) - ORCID: 0000-0002-7689-9628; pedrodantasfernandes@gmail.com -
ORCID: 0000-0001-5070-1030; geovanisoareslima@gmail.com - ORCID: 0000-0001-9960-1858
${ }^{2}$ Universidade Federal do Amapá/Coordenação do Curso de Licenciatura em Educação do Campo: Agronomia e Biologia. Mazagão, AP. E-mail:
jf.su@hotmail.com - ORCID: 0000-0001-8768-0261
${ }^{3}$ Universidade Federal de Sergipe/Centro de Ciências Agrárias do Sertão/Núcleo de Graduação em Educação em Ciências Agrárias e da Terra. Nossa
Senhora da Glória, SE E-mail: marcoseric@ufs.br - ORCID: 0000-0001-9087-3662
${ }^{4}$ Universidade Federal Rural do Semi-Árido/Centro de Ciências Agrárias/Programa de Pós-Graduação em Manejo de Solo e Água. Mossoró, RN. E-mail:
vanies_agronomia@hotmail.com - ORCID: 0000-0001-6585-8161

\section{Key words:}

Gossypium hirsutum L.

saline stress

phenological stages

\begin{abstract}
A B S T R A C T
Using saline water in the agricultural activity has become a reality in several regions of the world. Due to the increase in the demand for fresh water, it is necessary to use cultivation strategies and genotypes tolerant to saline stress to make the production viable. In this context, effects of irrigation management strategies with low-salinity water $\left(0.8 \mathrm{dS} \mathrm{m}^{-1}\right)$ and high-salinity water $\left(9.0 \mathrm{dS} \mathrm{m}^{-1}\right)$ were evaluated, varying the phenological stages of the plants, on the growth and fiber quality of colored cotton. Three cotton cultivars submitted to seven irrigation management strategies were used, constituting a $3 \times 7$ factorial scheme, in a randomized block design with three replicates, in plots and in protected environment. Saline water irrigation in the vegetative and flowering stages can be used in cotton cultivation with the lowest losses of growth, phytomass accumulation and fiber quality. Saline water application during boll development is detrimental to the growth and quality of cotton fiber. The genotype BRS Topázio is tolerant to water salinity, with better fiber length, regardless of the development stage.
\end{abstract}

\section{Palavras-chave:}

Gossypium hirsutum L.

estresse salino

fases fenológicas

\section{Crescimento e qualidade da fibra do algodoeiro colorido sob estratégias de manejo da salinidade}

\section{R E S U M O}

O uso de água salina na atividade agrícola vem se tornando uma realidade em diversas regiões do mundo, devido ao aumento na demanda de água doce, faz-se necessário o uso de estratégias de cultivo e genótipos tolerantes ao estresse salino que viabilizem a produção. Nesse contexto, objetivou-se avaliar neste estudo os efeitos de estratégias de manejo da irrigação com águas de baixa $\left(0,8 \mathrm{dS} \mathrm{m}^{-1}\right)$ e alta salinidade $\left(9,0 \mathrm{dS} \mathrm{m}^{-1}\right)$, variando as fases fenológicas das plantas, sobre o crescimento e qualidade de fibra de algodoeiros coloridos. Foram utilizados três cultivares de algodoeiro colorido submetidos a sete estratégias de manejo de irrigação, constituindo um fatorial $3 \times 7$, no delineamento de blocos casualizados e três repetições, com cultivo em vasos e em ambiente protegido. A irrigação com água salina nas fases vegetativa e de floração pode ser utilizada no cultivo do algodoeiro com as menores perdas no crescimento, acúmulo de fitomassa e qualidade de fibra. A aplicação da água salina na formação da produção foi prejudicial à qualidade de fibra do algodoeiro. O genótipo BRS Topázio obteve fibras de melhor qualidade sob irrigação com água de alta salinidade, quando comparado as demais cultivares estudadas. 


\section{INTRODUCTION}

Environmental stresses are responsible for limiting crop development, particularly saline stress, which in turn may determine crop yield, depending on the period of exposure, seed germination, vegetative growth, flowering and fruiting. This mainly occurs due to the reduction in the osmotic potential of the soil solution and may also lead to ionic toxicity, nutritional imbalance or both, because of the excessive accumulation of certain ions in plant tissues (Mguis et al., 2012; Hanin et al., 2016).

Despite the risks imposed by saline stress, saline water irrigation is increasingly necessary, given the limitation of water resources associated with the negative water balance occurring in a fair portion of the cycle of crops (Aydin et al., 2012). Nevertheless, its use requires improvements in water management, soil maintenance and cultivation of salt-tolerant crops (Oster, 1994).

Cotton is among the crops considered as salt-tolerant and plays a fundamental role in the Brazilian economy (Maas \& Hoffman, 1977; Alves et al., 2008). Although classified as salttolerant, cotton is often negatively affected by water salinity, especially in the initial development stage (Ashraf, 2002).

Sensitivity or tolerance to saline stress must be evaluated in different development stages of the plants (Iqbal et al., 2011). However, little has been studied on the tolerance of colored cotton to salinity, in each development stage and how plant recovery occurs, in growth and production, after the exposure to saline stress.

In this context, this study aimed to evaluate the effects of management strategies with saline water irrigation, varying the phenological stages of the plants, on the growth and fiber quality of colored cotton cultivars.

\section{Material ANd Methods}

The experiment was carried out in protected environment (greenhouse) at the Center for Technology and Natural Resources - CTRN of the Federal University of Campina Grande - UFCG, located in the municipality of Campina Grande, Paraíba, Brazil (07 $15^{\prime}$ 18” S; 35 52' 28” W; 550 m)

The experimental design was in randomized blocks, in a $3 \times 7$ factorial scheme, corresponding to three cotton genotypes (G1 - BRS Rubi; G2 - BRS Topázio; G3 - BRS Safira) and seven management strategies with saline water irrigation, varying according to plant phenological stages: vegetative (A) - from $1^{\text {st }}$ true leaf appearance to $1^{\text {st }}$ flower anthesis; flowering (B) - from $1^{\text {st }}$ flower anthesis to $1^{\text {st }}$ boll opening; boll development $(\mathrm{C})$ from $1^{\text {st }}$ boll opening to final harvest. Combined, the factors resulted in 21 treatments, with three replicates and three plants per plot, totaling 189 plants.

Cotton plants were irrigated with low-salinity water $(0.8$ $\mathrm{dS} \mathrm{m}^{-1}$ - index 1) and high-salinity water $\left(9.0 \mathrm{dS} \mathrm{m}^{-1}\right.$ - index 2$)$; applied through different management strategies: $\mathrm{T} 1-\mathrm{A}_{1} \mathrm{~B}_{1} \mathrm{C}_{1}$ plants irrigated with non-saline water $\left(0.8 \mathrm{dS} \mathrm{m}^{-1}\right)$ along the entire cycle - identified by the index 1 in the phenological stages; $\mathrm{T} 2-\mathrm{A}_{2} \mathrm{~B}_{1} \mathrm{C}_{1}$ - plants under saline stress in the vegetative stage (index 2 in stage $A$ ); T3 - $A_{1} B_{2} C_{1}$ - plants subjected to saline stress in the flowering stage (index 2 in stage $B$ ); T4 - $A_{1} B_{1} C_{2}$ irrigation with water of high electrical conductivity in the boll development stage (index 2 in stage $\mathrm{C}$ ); T5 - $\mathrm{A}_{2} \mathrm{~B}_{1} \mathrm{C}_{2}$ - plants irrigated with saline water in vegetative and boll development stages; $\mathrm{T} 6-\mathrm{A}_{2} \mathrm{~B}_{2} \mathrm{C}_{1}$ - irrigation with saline water successively in vegetative and flowering stages; and $\mathrm{T} 7-\mathrm{A}_{1} \mathrm{~B}_{2} \mathrm{C}_{2}$ - plants under saline stress in the flowering and boll development stages.

Plants were grown in 20 -L plastic pots $(35 \mathrm{~cm}$ high, $31 \mathrm{~cm}$ top diameter, $20 \mathrm{~cm}$ bottom diameter), covered at the bottom with a fine-mesh screen to avoid soil loss and connected to a hose and a collector, to collect the drained water. A 3-cm layer of fine gravel was placed on the screen, followed by $4.5 \mathrm{~kg}$ of properly sieved material from a eutrophic Regolithic Neosol, with loamy sand texture. Its physical-hydraulic and chemical attributes, determined according to methodology proposed by Claessen (1997), were: $\mathrm{Ca}^{2+}=2.37 \mathrm{cmol} \mathrm{kg}^{-1} ; \mathrm{Mg}^{2+}=3.09 \mathrm{cmol}_{\mathrm{c}} \mathrm{kg}^{-1} ; \mathrm{Na}^{+}$ $=0.37 \mathrm{cmol}_{\mathrm{c}} \mathrm{kg}^{-1} ; \mathrm{K}^{+}=0.18 \mathrm{cmol}_{\mathrm{c}} \mathrm{kg}^{-1} ;$ organic matter $=21.20$ dag $\mathrm{kg}^{-1} ; \mathrm{pH}$ of saturation paste $=5.8$; electrical conductivity of the saturation extract $=0.20 \mathrm{dS} \mathrm{m}^{-1}$; water content at 33.42 $\mathrm{kPa}=11.48$ dag $\mathrm{kg}^{-1}$ and at $1519.5 \mathrm{kPa}=2.41 \mathrm{dag}^{\mathrm{k} g}{ }^{-1}$.

Basal NPK fertilization was performed based on recommendations for pot experiments (Novais et al., 1991), by applying 100, 300 and $150 \mathrm{mg} \mathrm{kg}^{-1}$ of soil of $\mathrm{N}, \mathrm{P}$ and $\mathrm{K}$, respectively, in the forms of ammonium sulfate, single superphosphate and potassium chloride. The recommendation of $\mathrm{P}$ was entirely applied at planting, along with $1 / 3$ of the recommendations of $\mathrm{N}$ and $\mathrm{K}$; the remaining two thirds were applied through the irrigation water at 45 and 65 days after sowing (DAS).

The low-salinity water used in irrigation $\left(0.8 \mathrm{dS} \mathrm{m}^{-1}\right)$ was obtained by diluting water from the public supply system in rainwater, whereas the water corresponding to the high ECw $\left(9.0 \mathrm{dS} \mathrm{m}^{-1}\right)$ was prepared in such a way to have an equivalent proportion of 7:2:1, between $\mathrm{Na}: \mathrm{Ca}: \mathrm{Mg}$, respectively, based on the methodology found in Richards (1954). Sowing was carried out after soil moisture was elevated to the maximum retention level, in all experimental units, using low-salinity water $\left(0.8 \mathrm{dS} \mathrm{m}^{-1}\right)$, by planting five seeds per pot at $3 \mathrm{~cm}$ depth. Thinning was performed 30 DAS, leaving only one plant per pot.

Irrigations were daily applied at $17 \mathrm{~h}$. The volume applied in each irrigation event was estimated by water balance, according to the following equation: $\mathrm{WC}=(\mathrm{Va}-\mathrm{Vd}) /(1-\mathrm{LF})$, in which WC is volume of water to be applied, considering the water volume applied to the plants ( $\mathrm{Va}$ ) in the previous irrigation; $\mathrm{Vd}$ is the volume drained, quantified in the anterior irrigation; and LF is the leaching fraction, applied at 0.20 every 15 days.

At 37, 59 and 113 DAS, plants were subjected to evaluation of the following parameters: number of leaves (NL), plant height $(\mathrm{PH})$ and stem diameter (SD). Shoot dry phytomass (SDP), fiber length (Upper Half Mean - UHM) and short fiber index (SFI) were evaluated at 113 DAS. The number of leaves was counted considering leaves larger than $3 \mathrm{~cm}$. Plant height was measured from the base to the apical bud of the main branch, whereas stem diameter was measured $2 \mathrm{~cm}$ above the base of the plant. 
To determine dry phytomass, plants were collected, placed in paper bags, dried in forced-air oven at $65^{\circ} \mathrm{C}$ and then weighed. The bolls of each plot were sent to analysis, at the Laboratory of Fibers of Embrapa Cotton using the device HVI (High Volume Instruments), to obtain fiber length ( $\mathrm{mm}$ ) and short fiber index (\%).

The data were evaluated and, when there was significance by F test, Scott-Knott means grouping test $(\mathrm{p}<0.05)$ was applied to salinity management strategies and Tukey test $(\mathrm{p}<0.05)$ was applied to cotton genotypes (Ferreira, 2011).

\section{Results AND Discussion}

According to the test of means for the salinity management strategies on the number of leaves at 37 DAS (Figure 1A), the treatments $\mathrm{T} 1-\mathrm{A}_{1} \mathrm{~B}_{1} \mathrm{C}_{1}$ and $\mathrm{T} 4-\mathrm{A}_{1} \mathrm{~B}_{1} \mathrm{C}_{2}$ were superior to the others. However, at 59 and 113 DAS, irrigation with $9 \mathrm{dS} \mathrm{m}^{-1}$ water in the vegetative stage ( $\mathrm{T} 2-\mathrm{A}_{2} \mathrm{~B}_{1} \mathrm{C}_{1}$ ), despite initially causing reduction in leaf production, immediately after saline water application stopped in the other stages, led to a compensation in the vegetative growth and plants produced new leaves. Khorsandi \& Anagholi (2009), studying the effect of different salt levels $\left(2,10\right.$ and $\left.20 \mathrm{dS} \mathrm{m}^{-1}\right)$ in different phenological stages, also observed that cotton is sensitive to salinity during the initial growth; however, after saline stress was suspended, cotton plants resumed their growth.
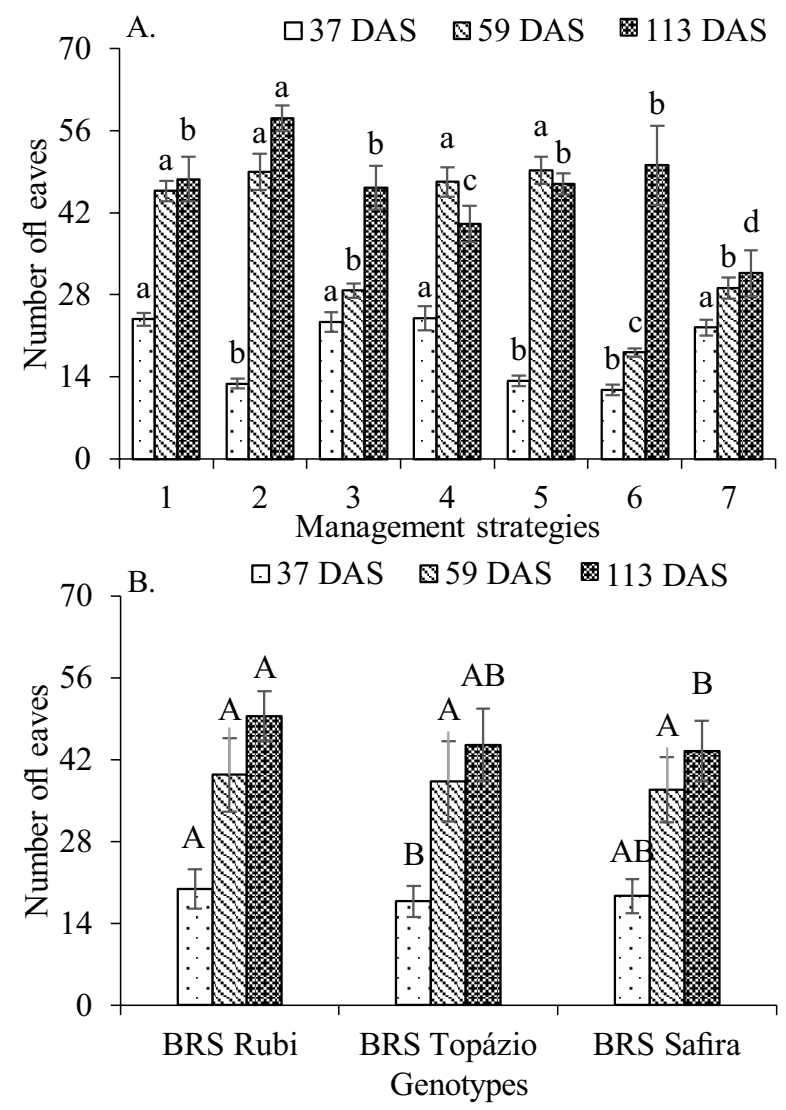

Same lowercase letters indicate no significant difference between management strategies (Scott-Knott, $p<0.05$ ) and same uppercase letters indicate no significant difference between genotypes (Tukey, $p<0.05$ ); Bars represent the standard error of the mean for management strategies $(n=9)$ and genotypes $(n=21)$

Figure 1. Mean number of leaves of cotton plants under different strategies of salinity management (A) and genotypes (B) at 37, 59 and 113 days after sowing (DAS)
Differences between the colored cotton genotypes regarding leaf production were observed only at 37 and 113 DAS, and BRS Rubi was superior to the others with mean value of 49.43 leaves per plant i.e. increment of $12.01 \%$ compared with BRS Safira at the end of the cycle, at 113 DAS (Figure 1B). These differences in the number of leaves can be explained by the different genetic constitutions of the genotypes evaluated. Differences of growth between cotton genotypes were also reported by Hanif et al. (2008).

When saline stress was applied during the fruiting stage ( $\mathrm{T} 4-\mathrm{A}_{1} \mathrm{~B}_{1} \mathrm{C}_{2}$ ), there were no significant differences in cotton stem diameter (Figure 2A). This fact is an indication that the exposure to irrigation water salinity during this stage has smaller effect on plant growth. Another relevant aspect was the recovery of plants under the management strategies T2, T3 and T6 immediately after the end of salinity application. Oliveira et al. (2008), working with cotton cultivars irrigated with water of different salinity levels $\left(0.5\right.$ to $\left.8.5 \mathrm{dS} \mathrm{m}^{-1}\right)$ from 21 to 56 days after planting, observed that the growth of three cultivars was inhibited by the increase in salt concentration in the irrigation water.

Among the cotton genotypes, greater growth in stem diameter was found in BRS Topázio and BRS Safira, and difference between BRS Safira and BRS Rubi was observed only at 59 and 113 DAS, with reductions of 28.79 and $30.92 \%$ between these genotypes, respectively (Figure 2B). Similar
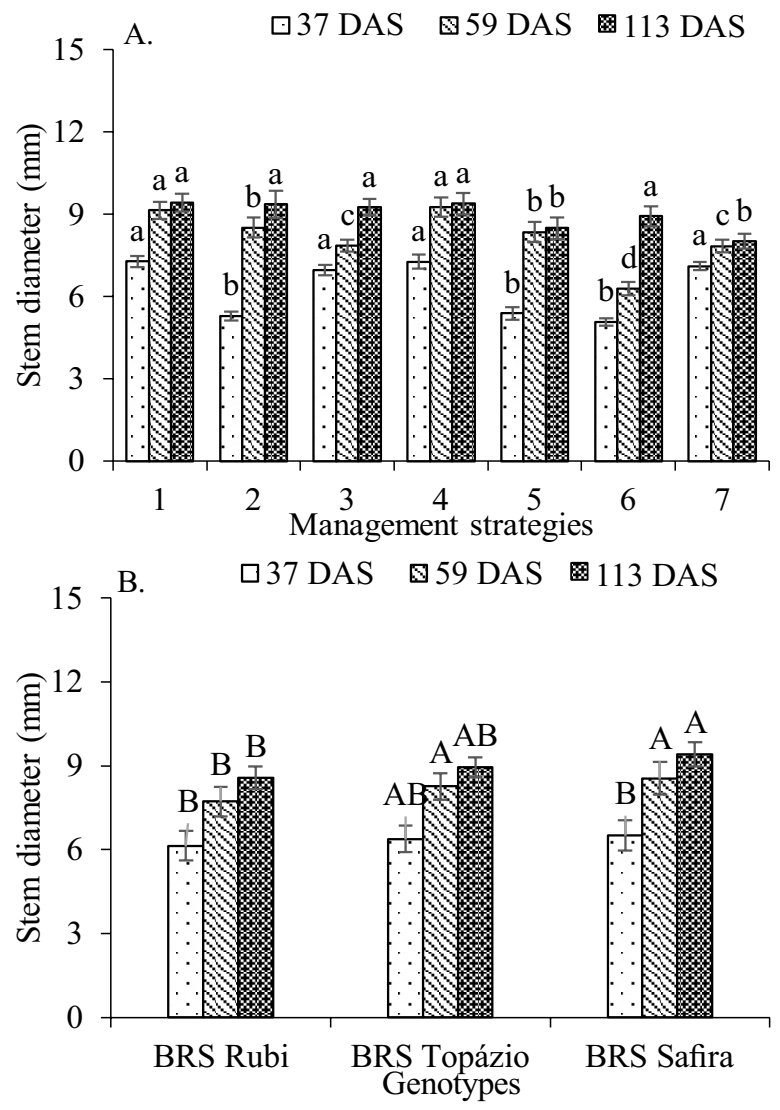

Same lowercase letters indicate no significant difference between management strategies (Scott-Knott, $p<0.05$ ) and same uppercase letters indicate no significant difference between genotypes (Tukey, $p<0.05$ ); Bars represent the standard error of the mean for management strategies $(n=9)$ and genotypes $(n=21)$

Figure 2. Mean stem diameter of cotton under different strategies of salinity management $(A)$ and genotypes $(B)$ at 37, 59 and 113 days after sowing (DAS) 
results were obtained by Basal (2010), who reported differences in the stem diameter growth of cotton genotypes, and the differences in plant height can be attributed to the genetic constitution of each genotype.

For cotton height, when saline water was applied during the flowering stage ( $\mathrm{T} 3-\mathrm{A}_{1} \mathrm{~B}_{2} \mathrm{C}_{1}$ ) and flowering/boll development (T7 - $\mathrm{A}_{1} \mathrm{~B}_{2} \mathrm{C}_{2}$ ), plant height at the end of the cycle decreased by 20.89 and $31.55 \%$, i.e., reductions equivalent to 23.07 and $34.84 \mathrm{~cm}$, compared with plants irrigated with $0.8 \mathrm{dS} \mathrm{m}^{-1}$ water along the entire cycle ( $\mathrm{T} 1-\mathrm{A}_{1} \mathrm{~B}_{1} \mathrm{C}_{1}$ ) (Figure $3 \mathrm{~A}$ ). Based on this observation, it can be inferred that cotton is more sensitive to irrigation water salinity in the flowering and boll development stages. This is consistent with the results found by Khorsandi \& Anagholi (2009), who claimed that high water salinity during these stages significantly reduced cotton yield.

When the three genotypes were evaluated at 37,59 and 113 DAS (Figure 3B), BRS Safira showed greater height (57.25; 97.17 and $115.42 \mathrm{~cm}$ ) differing from BRS Rubi and BRS Topázio. Corroborating the present study, Ferraz (2012) also found greater growth in plant height for the genotype BRS Safira, studying the behavior of different herbaceous cotton genotypes subjected to foliar application of silicon under semi-arid conditions.

Based on the mean values of shoot dry phytomass (SDP) at 113 DAS, the genotypes BRS Rubi (Figure 4A), BRS Topázio (Figure 4B) and BRS Safira (Figure 4C), when subjected to saline stress during flowering and boll development (T7 $\mathrm{A}_{1} \mathrm{~B}_{2} \mathrm{C}_{2}$ ) showed reductions of $44.56,42.53$ and $49.51 \%$ in SDP compared with plants under no saline stress along the entire cycle ( $\left.\mathrm{T} 1-\mathrm{A}_{1} \mathrm{~B}_{1} \mathrm{C}_{1}\right)$, respectively. Higher SDP accumulation was found in the strategies T1 - A1B1C1 (94.68; 77.73 and $95.87 \mathrm{~g})$ and $\mathrm{T} 2-\mathrm{A}_{2} \mathrm{~B}_{1} \mathrm{C}_{1}(90.48 ; 77.71$ and $93.42 \mathrm{~g})$ in the cotton genotypes at 113 DAS (Figure 4). These results just reinforce that there are differences in the effects of salinity between plant species, between genotypes of the same species and between development stages of the same genotype (Yao et al., 2010; Tiwari et al., 2013).

Among the three genotypes under no saline stress application ( $\mathrm{T} 1-\mathrm{A}_{1} \mathrm{~B}_{1} \mathrm{C}_{1}$ ), greater fiber length was found in BRS Topázio (29.67 mm), differing from BRS Rubi and BRS Safira, whose UHM values were 23.08 and $24.09 \mathrm{~mm}$, respectively. The genotypes BRS Topázio and BRS Safira, when
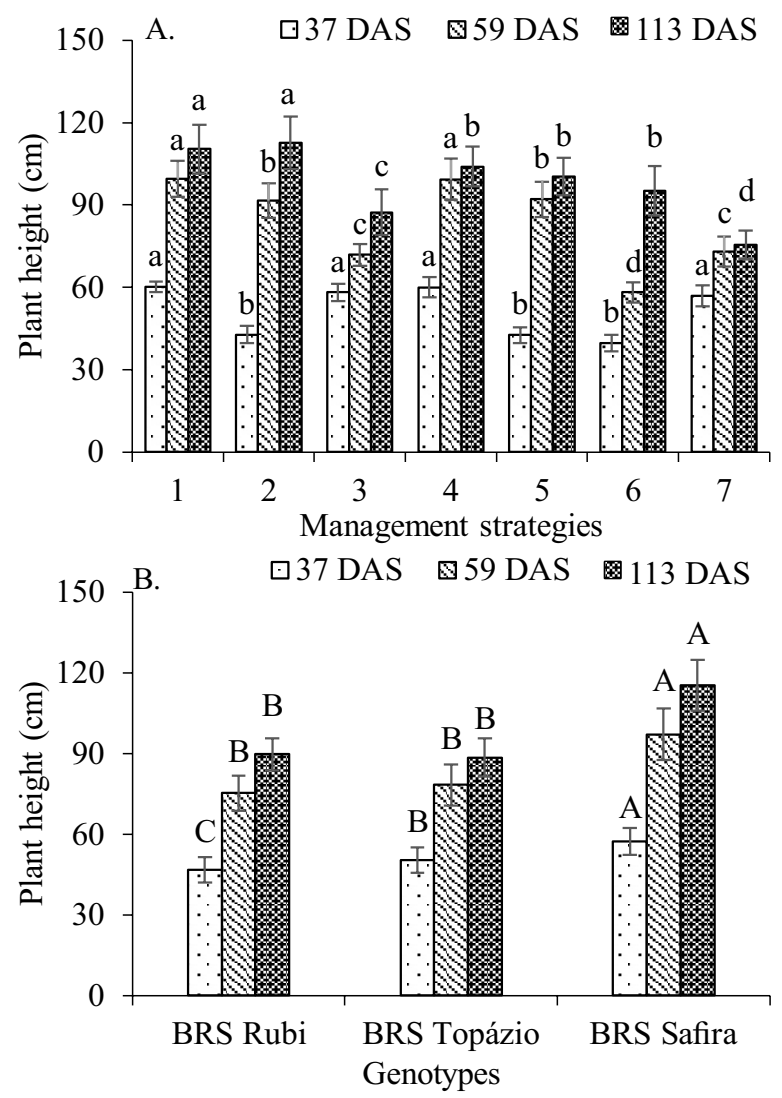

Same lowercase letters indicate no significant difference between management strategies (Scott-Knott, $p<0.05$ ) and same uppercase letters indicate no significant difference between genotypes (Tukey, $p<0.05$ ); Bars represent the standard error of the mean for management strategies $(n=9)$ and genotypes $(n=21)$

Figure 3. Mean plant height of cotton under different strategies of salinity management (A) and genotypes (B) at 37,59 and 113 days after sowing (DAS)

subjected to saline stress during fruiting $\left(\mathrm{T} 4-\mathrm{A}_{1} \mathrm{~B}_{1} \mathrm{C}_{2}\right)$, showed reductions in UHM, compared with plants under no saline stress, of 5.58, 6.52 and $4.81 \%$ in BRS Topázio, and 12.31, 4.01 and $6.86 \%$ in BRS Safira with the managements $\mathrm{T} 4-\mathrm{A}_{1} \mathrm{~B}_{1} \mathrm{C}_{2}$, $\mathrm{T} 5-\mathrm{A}_{2} \mathrm{~B}_{1} \mathrm{C}_{2}$ and $\mathrm{T} 7-\mathrm{A}_{1} \mathrm{~B}_{2} \mathrm{C}_{2}$, respectively (Figure $5 \mathrm{~A}, \mathrm{~B}$ and C). Peng et al. (2016) claim that cotton fiber length depends mostly on genetic factors, but effects associated with saline stress must be considered, especially on properties inherent to fiber maturation.

There was significant interaction between salinity management strategies and genotypes for the short fiber index, with

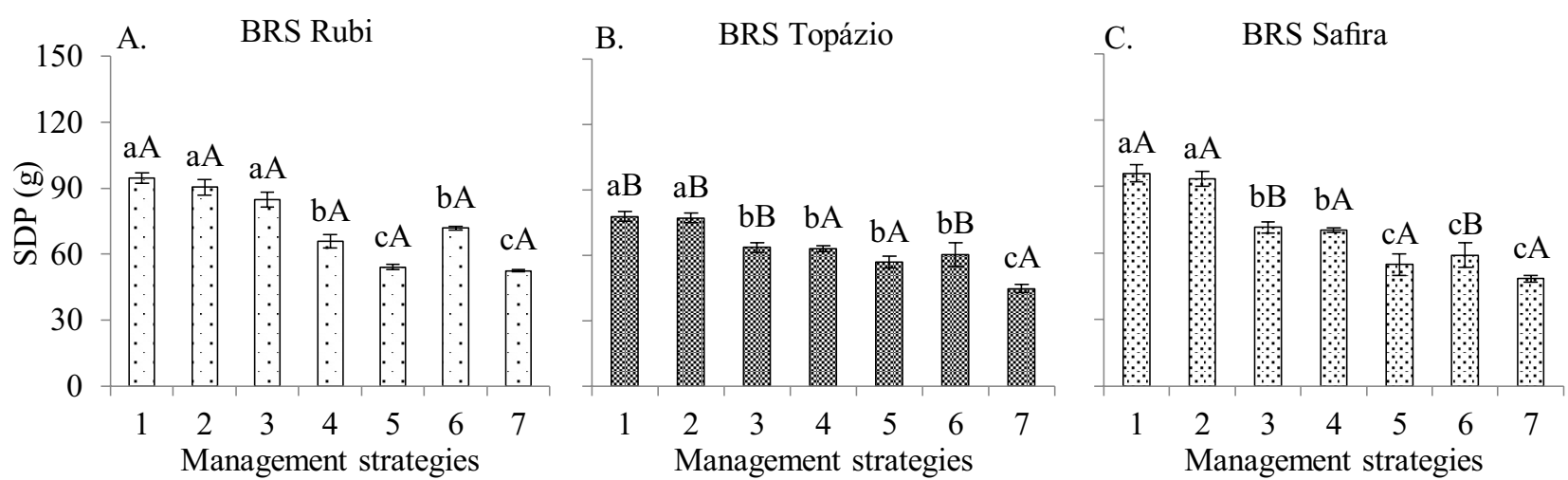

Same lowercase letters indicate no significant difference between management strategies (Scott-Knott, $p<0.05$ ) and same uppercase letters indicate no significant difference between genotypes for same management strategy (Tukey, $p<0.05)$; Bars represent the standard error of the mean $(n=9)$

Figure 4. Follow-up analysis of the interaction between management strategies and the genotypes BRS Rubi (A) BRS Safira (B) and BRS Topázio (C) for shoot dry phytomass (SDP) at 113 days after sowing (DAS) 

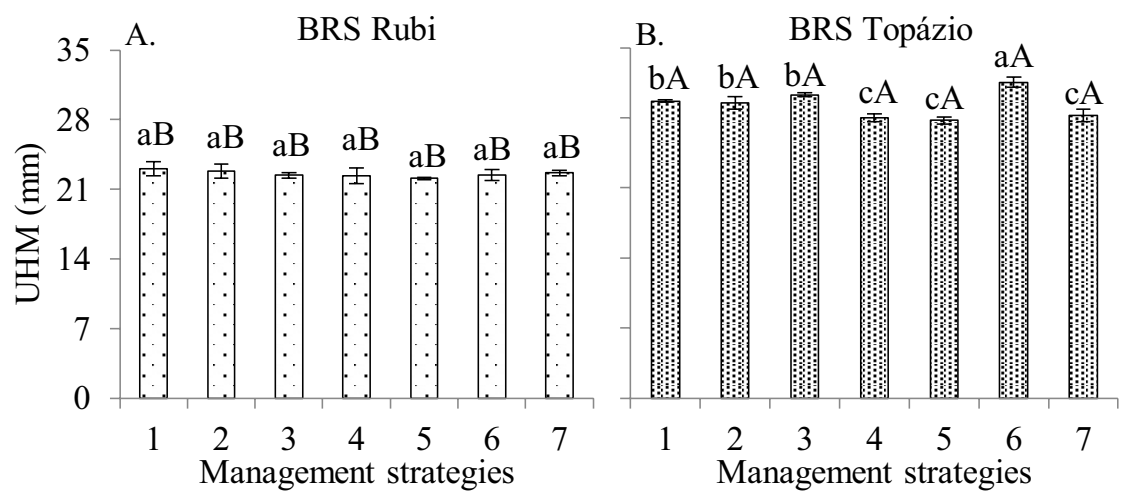

C.

BRS Safira

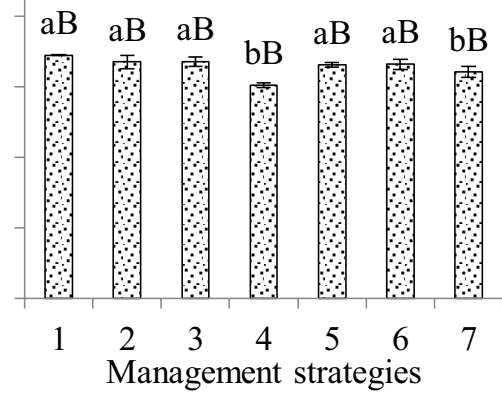

Same lowercase letters indicate no significant difference between management strategies (Scott-Knott, $p<0.05$ ) and same uppercase letters indicate no significant difference between genotypes for same management strategy (Tukey, $p<0.05)$; Bars represent the standard error of the mean $(n=9)$

Figure 5. Follow-up analysis of the interaction between management strategies and the genotypes BRS Rubi (A) BRS Safira (B) and BRS Topázio (C) for fiber length (UHM) at 113 days after sowing (DAS)
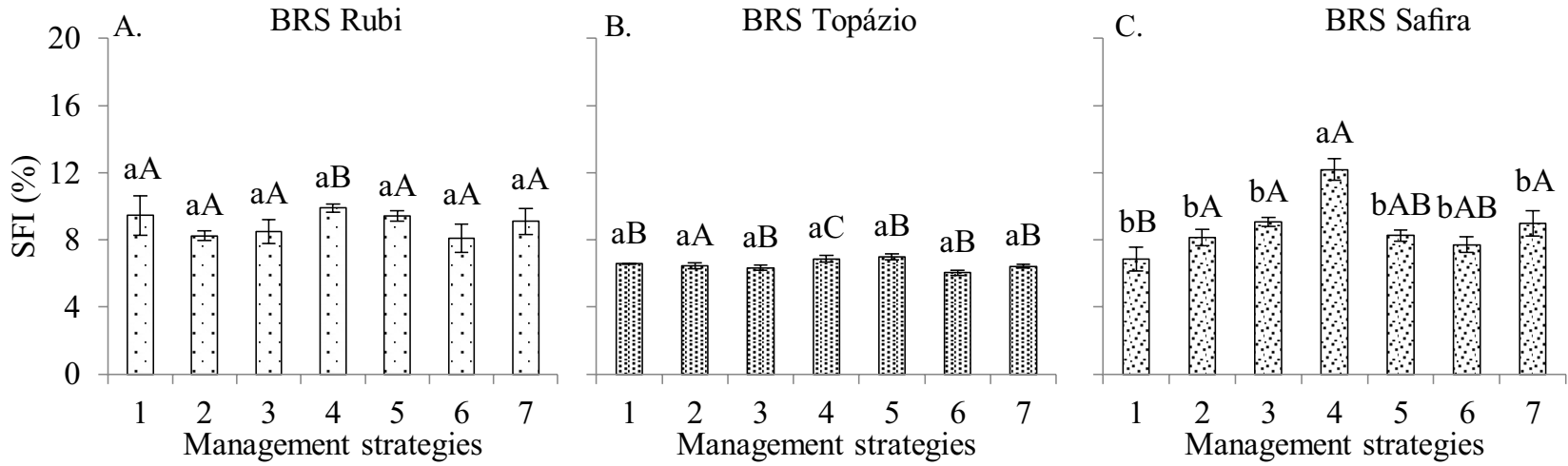

Same lowercase letters indicate no significant difference between management strategies (Scott-Knott, $p<0.05)$ and same uppercase letters indicate no significant difference between genotypes for same manegement strategy (Tukey, $p<0.05$ ); Bars represent the standard error of the mean $(n=9)$

Figure 6. Follow-up analysis of the interaction between management strategies and the genotypes BRS Rubi (A) BRS Safira (B) and BRS Topázio (C) for short fiber index (SFI) at 113 days after sowing (DAS)

variations between strategies only in the genotype BRS Safira, whose highest SFI (12.18\%) was found in plants subjected to saline stress in the fruiting stage $\left(\mathrm{T} 4-\mathrm{A}_{1} \mathrm{~B}_{1} \mathrm{C}_{2}\right.$ ) (Figure 6A, B and $\mathrm{C}$ ). Thus, it becomes evident that saline water irrigation in the fruiting stage caused a decline in fiber quality, leading to reduction in length with the increment in short fiber index (Silva et al., 2010).

As the trends observed for fiber length, the lowest percentages of short fibers $(6.62 \%)$ were found in the genotype BRS Topázio, regardless of the salinity management strategies (Figure 6). Cunha Neto et al. (2015), analyzing the genetic divergence between progenitors of white fibers and colored fibers, also found lower SFI in the genotype BRS Topázio (9.74\%), which is positive because the lower this index, the better the resistance and regularity of the threads, since they influence processes subsequent to fabric weaving, such as torsional resistance and yarn appearance (Jerônimo et al., 2014).

\section{Conclusions}

1. Saline water irrigation in vegetative and flowering stages can be used in cotton cultivation with the lowest losses of growth, phytomass accumulation and fiber quality.

2. Saline water application during boll development is detrimental to cotton fiber quality.
3. The genotype BRS Topázio obtained better-quality fibers under irrigation with high-salinity water, compared with the other cultivars studied.

\section{ACKnOWledgments}

To the Coordination for the Improvement of Higher Education Personnel - CAPES, for granting the scholarship to the first author.

\section{Literature Cited}

Alves, L. R. A.; Barros, G. S. de C.; Bacchi, M. R. P. Produção e exportação de algodão: Efeitos de choques de oferta e de demanda. Revista Brasileira de Economia, v.62, p.381-405, 2008. https://doi. org/10.1590/S0034-71402008000400002

Ashraf, M. Salt tolerance of cotton: Some new advances. Critical Reviews in Plant Sciences, v.21, p.1-30, 2002. https://doi. org/10.1080/0735-260291044160

Aydin, A.; Kant, C.; Turan, M. Humic acid application alleviate salinity stress of bean (Phaseolus vulgaris L.) plants decreasing membrane leakage. African Journal of Agricultural Research, v.7, p.10731086, 2012. https://doi.org/10.5897/AJAR10.274

Basal, H. Response of cotton (Gossypium hirsutum L.) genotypes to salt stress. Pakistan Journal of Botany, v.42, p.505-511, 2010.

Claessen, M. E. C. (org.). Manual de métodos de análise de solo. 2.ed. Rio de Janeiro: Embrapa CNPS, 1997. 212p. Documentos, 1 
Cunha Neto, J.; Bertini, C. H. C. de M.; Silva, A. P. M. da. Divergência genética entre genitores de algodoeiro de fibras brancas e coloridas. Revista Brasileira de Ciências Agrárias, v.10, p.492-498, 2015. https://doi.org/10.5039/agraria.v10i4a4883

Ferraz, R. L. S. Crescimento, fisiologia e produção do algodoeiro sob efeito do silício via foliar. Campina Grande: UFCG, 2012. 130p. Dissertação Mestrado

Ferreira, D. F. Sisvar: A computer statistical analysis system. Ciência e Agrotecnologia, v.35, p.1039-1042, 2011. https://doi.org/10.1590/ S1413-70542011000600001

Hanif, M.; Noor, E.; Murtaza, N.; Qayyum, A.; Malik, W. Assessment of variability for salt tolerance at seedling stage in Gossypium hirsutum L. Journal of Food Agriculture and Environment, v.6, p.134-138, 2008.

Hanin, M.; Ebel, C.; Ngom, M.; Laplaze, L.; Masmoudi, K. New insights on plant salt tolerance mechanisms and their potential use for breeding. Frontiers in Plant Science, v.7, p.1-17, 2016. https://doi.org/10.3389/fpls.2016.01787

Iqbal, N.; Nazar, R.; Syeed, S.; Masood, A.; Khan, N. A. Exogenouslysourced ethylene increases stomatal conductance, photosynthesis, and growth under optimal and deficient nitrogen fertilization in mustard. Journal of Experimental Botany, v.62, p.4955-4963, 2011. https://doi.org/10.1093/jxb/err204

Jerônimo, J. F.; Almeida, F. de A. C.; Silva, O. R. R. F. da; Brandão, Z. N.; Sofiatti, V.; Gomes, J. P. Qualidade da semente e fibra de algodão na caracterização do descaroçador de 25 serras. Revista Brasileira de Engenharia Agrícola e Ambiental, v.18, p.664-671, 2014. https://doi.org/10.1590/S1415-43662014000600015

Khorsandi, F; Anagholi, A. Reproductive compensation of cotton after salt stress relief at different growth stages. Journal Agronomy \& Crop Science, v.195, p.278-283, 2009. https://doi.org/10.1111/ j.1439-037X.2009.00370.x

Maas, E. V.; Hoffman, G. J. Crop salt tolerance-current assessment. Journal of Irrigation and Drainage Division of ASCE, v.103, p.115-134, 1977.
Mguis, K.; Albouchi, A.; Khadhri, A.; Abassi, M.; Yakoubi-Tej, M.; Mahjoub, A.; Ouerghi, Z.; Brahim, N. B. Adjustments in leaf water relations of wild wheat relative Aegilops geniculata Roth. and wheat (Triticum durum Desf.) plants grown in a salinity gradient. Australian Journal of Crop Science, v.6, p.768-776, 2012.

Novais, R. F.; Neves, J. C. L.; Barros, N. F. Ensaio em ambiente controlado. In: Oliveira, A. J. Métodos de pesquisa em fertilidade do solo. Brasília: EMBRAPA-SEA, 1991. p.189-253.

Oliveira, A. M.; Oliveira, A. M. P.; Dias, N. S.; Medeiros, J. F. Irrigação com água salina no crescimento inicial de três cultivares de algodão. Irriga, v.13, p.467-475, 2008.

Oster, J. D. Irrigation with poor quality water. Agricultural Water Management, v.25, p.271-279. 1994. https://doi.org/10.1016/03783774(94)90064-7

Peng, J.; Zhang, L.; Liu, J.; Luo, J.; Zhao, X.; Dong, H.; Ma, Y.; Sui, N.; Zhou, Z.; Meng, Y. Effects of soil salinity on sucrose metabolism in cotton fiber. Plos One, v.11, p.1-16, 2016. https://doi.org/10.1371/ journal.pone.0156398

Richards, L. A. Diagnosis and improvement of saline and alkali soils, Washington, U.S.: Department of Agriculture, 1954. 160p.

Silva, O. R. R. F. da; Sofiatti, V.; Santana, J. C. F. de; Wanderley, M. J. R.; Santos, J. W. dos. Impacto do beneficiamento sobre o número de neps e quantidade de impurezas da fibra do algodão. Revista Brasileira de Engenharia Agrícola e Ambiental, v.14, p.107-112, 2010. https://doi.org/10.1590/S1415-43662010000100015

Tiwari, R. S.; Picchioni, G. A.; Steiner, R. L.; Jones, D. C.; Hughs, S. E.; Zhang, J. F. Genetic variation in salt tolerance during seed germination in a backcross inbred line population and advanced breeding lines derived from Gossypium hirsutum x G. barbadense. Crop Science, v.53, p.1974-1982, 2013. https://doi.org/10.2135/ cropsci2013.01.0028

Yao, X.; Horie, T.; Xue, S.; Leung, H. Y.; Katsuhara, M.; Brodsky, D. E.; Wu, Y.; Schroeder, J. I. Differential sodium and potassium transport selectivities of the rice OsHKT $2 ; 1$ and $\mathrm{OsHKT}_{2 ; 2}$ transporters in plant cells. Plant Physiology, v.152, p.341-355, 2010. https://doi.org/10.1104/pp.109.145722 